Pobrane z czasopisma New Horizons in English Studies http://newhorizons.umcs.pl Data: 26/04/2023 13:47:22

New Horizons in English Studies 6/2021

\title{
LITERATURE
}

@

\author{
Bożena Kucała \\ Jagiellonian University in Kraków, Poland \\ BOZENA.KUCALA@UJ.EDU.PL \\ HTTPS://ORCID.ORG/ OOOO-0002-9882-9305
}

\section{The Magical and the Mundane in Graham Swift's Here We Are}

Our revels now are ended. These our actors, As I foretold you, were all spirits and Are melted into air, into thin air:

And, like the baseless fabric of this vision, The cloud-capp'd towers, the gorgeous palaces,

The solemn temples, the great globe itself, Yea, all which it inherit, shall dissolve And, like this insubstantial pageant faded, Leave not a rack behind. We are such stuff As dreams are made on, and our little life Is rounded with a sleep.

William Shakespeare, The Tempest

I think the world cannot bear to be only what it is. The world always wants another world, a shadow, an echo, a model of itself.

Graham Swift, Out of this World 


\begin{abstract}
This article places Graham Swift's latest novel Here We Are (2020) in the context of his previous writing and argues that much of his fiction is underpinned by the characters' desire to transcend the limitations of their ordinary lives and to seek solace or a temporary escape within the realm of illusion. The analysis aims to demonstrate that the opposition between the two realms is the central preoccupation in Here We Are. The wish to surmount the mundane is fulfilled quite literally through the protagonist's dedication to the practice of magic. The meaning of magic as a craft is briefly discussed, especially its quasi-religious connotations. It is also suggested that magic may be a tentative, personal answer to the problem of the "disenchantment" of the world, as diagnosed by Max Weber a hundred years ago. In Swift's novel, far from being only a set of professional skills, magic creates an illusory realm, alternative to and more appealing than daily life.
\end{abstract}

Keywords: Graham Swift, Here We Are, contemporary English fiction, magic in literature, disenchantment

\title{
Introduction: Graham Swift's Narrow Worlds
}

It has become a cliché in the criticism on the work of Graham Swift that his fiction is firmly grounded in ordinary life. Despite being an established name in the contemporary English novel, Swift does not attract as much popular or critical notice as some of his contemporaries, the reason being - as Daniel Lea contends - that "Swift's brand of intense attention to the detail of daily living and his nostalgic yearning for lost certainties appears old-fashioned and overly scrupulous" $(2005,4)$. Ironically, his best-known publication, which has come to be considered "the ultimate benchmark for evaluating Swift's work" (Dobrogoszcz and Goszczyńska 2020, vii), is not the most representative sample of his writing. Expansive in tone and subject matter as well as technically sophisticated, Swift's third novel, Waterland (1983), places individual trials, tragedies and tribulations against the universalising background of historical processes, thus lending itself to a variety of critical interpretations. However, an overview of the eleven novels and two collections of short stories Swift has published to date would suggest that it was his first novel, The Sweet Shop Owner (1980), that indicated more adequately the direction which the majority of his writing would take. The novel describes, in retrospect, the life of an inconspicuous, mediocre Londoner looking back over his mundane life, which has been deeply marked by failure, disillusion and self-effacement. A similar formula underpins Swift's later novel, The Light of Day (2003) - during the single day that the action covers, its middle-aged protagonist contemplates the longings and regrets of his routine existence. The claim made by Daniel Lea in his 2005 monograph on Swift still holds true for most of the writer's output:

Swift's fiction can be relatively easily summarised: it customarily involves monologic narration either by a single figure or by a group whose voices compete with each other; his narrators are principally men of late middle age who reflect upon their lives as a series of compromises, and who rue their failure to have been more than they were; they are men who 
are commonly ineffective in interpersonal relationships and exhibit none of the stereotypical characteristics of manly being. $(2005,2)$

Indeed, the majority of Swift's fiction evinces a "penchant for the parochial, the drab, and the unremarkable" (Dobrogoszcz and Goszczyńska 2020, vii). Typically, Swift's characters, whether male or female, are circumscribed by their ineffectual personality, their social circumstances and the narrowness of their locality. Starting (and often ending) on a small scale is a deliberate strategy on the part of the writer. In an interview with Stef Craps, Swift explained: "However 'global' we like to think we've become, it remains true that life is about our little corner, our little nook, our little niche, our little territory. It's a small world, but that small world opens up to the big world, and that's simply the way I go about things" (Craps 2009, 652). The tendency to explore the complexities of "narrow worlds" - as David Malcolm termed some of Swift's novels in his 2003 monograph - comes to the fore especially in the shabby urban setting of Last Orders (1996) and the provincial location of Wish You Were Here (2011). Swift's second collection of short stories, England and Other Stories (2014), has been quite unanimously described as a "chronicle of everyday lives" (Scholes 2014), "chronicles of the ordinary" (Seiffert 2014), and "the effluvia of ordinary life" (Kakutani 2015).

Yet, although the writer himself narrows down his settings, it would not be true to say that his characters uniformly or inevitably accept their entrapment in the ordinary and the mundane. Story-telling and constructing fictions are their favourite strategies for coping with reality. In Waterland, Tom Crick asks while addressing his secondary school students:

How do you surmount reality, children? How do you acquire, in a flat country, the tonic of elevated feelings? [...] How did the Cricks outwit reality? By telling stories. [...] And it is strange - or perhaps not strange, not strange at all, only logical - how the bare and empty Fens yield so readily to the imaginary - and the supernatural. $(1984,15)$

Tom's father imaginatively refashioned the flat landscape of the Fens by representing it to his sons as "a fairy-tale place" (1). The narrator recollects that:

my father, who was a superstitious man, liked to do things in such a way as would make them seem magical and occult. So he would always set his eel traps at night. Not because eel traps cannot be set by day, but because the mystery of darkness appealed to him. (1)

The protagonist of Wish You Were Here, who becomes the manager of a caravan site on the Isle of Wight, makes a living out of catering to people's dreams of escaping from the banality of daily life. His wife Ellie persuaded him to take up this occupation by appealing to his own fantasy of a holiday by the sea: "'Caravans,' Ellie had said, as if it were a magic word, the secret of the universe she'd been saving up to tell him. 
[...] Not that he'd resisted. And anyway for him the word did have a kind of magic" (2011, 62). In Ever After (1992), as David Malcolm observes, "[m]otifs of illusion are present from the opening pages" $(2003,154)$. The Paris that the narrator remembers from his childhood visit persists in his imagination as "a fairy-tale city [...] with its enchanted streets and eternal air of license felicity" $(1992,57)$. His wife's stage personas are artistic illusions, and so is the world of literary fiction that Bill Unwin immerses himself in. The protagonist has recourse to literary models while imposing fanciful plots on his life; from his early childhood until his failed suicide attempt, he remains committed to the illusory world of theatre. In Last Orders, a group of Londoners momentarily break their daily routines to carry out semi-funeral rites and to scatter their friend's ashes in the sea. By travelling towards Margate, they not only follow Jack's unsophisticated fantasies of an ideal holiday place but also half-consciously perform serious gestures of mourning and commemoration, not without certain religious overtones. As Wendy Wheeler intriguingly notes in her brief account of the novel, "[p] erhaps one of the most interesting things is the way in which, beneath the ordinary Bermondsey voices and lives, another language surprisingly emerges: the symbolic language of the spirit and the soul. No elevated language here, but, nonetheless, a glimpse of the sacred and the enchanted" $(1999,76-77)$.

\section{Here We Are: The Mundane and Beyond}

In this article, I wish to follow up Wheeler's observation and argue that much of Swift's fiction is underlain by the characters' yearning to surmount empirical reality, to move beyond the boundaries of the mundane and the ordinary; indeed, by a desire for some form of transcendence. This article focuses on Swift's most recent publication, Here We Are (2020), in which this strand in his fiction is explicitly articulated and becomes the central motif around which the novel revolves. In many respects, Swift's latest book resembles his other stories; the Swiftian scholar Donald P. Kaczvinsky identifies in it a number of familiar leitmotifs (2020, 98-99). Despite the writer's abiding concern with "the smallness of ordinary lives" (Lea 2005, 3), the role that magic plays in this novella is by no means an anomaly within his oeuvre. Read in the light of his previous fiction, Here We Are may be viewed as intensifying what Wheeler called the language of the enchanted, which has been intermittently present in Swift's narratives, implicitly or sometimes overtly, at least since his first collection of short stories, Learning to Swim and Other Stories (1982). ${ }^{1}$ Earlier occasional references to fairy tales, illusions or magic words coalesce into an open engagement with magical practices in Swift's latest novel. In relation to his other narratives, this open venture into the realm of the magical should not be seen as an aberration. Rather, it is an op-

1 One of the stories, "The Watch," features a watch with magical properties. Also, "Hypochondriac" and "Chemistry" contain "hints of supernatural motifs" (Malcolm 2003, 71). 
portunity that some of the characters in Swift's other stories already glimpsed, and perhaps even tried to embrace, but usually timidly and unsuccessfully. In Here We Are, the alignment of the relations between the palpably real and the illusory readjusts the balance in favour of the latter. Discussing the magician's craft, Graham M. Jones states that "some notion of wonder or surprise invariably emerges from any attempt to explain magic's attraction" $(2011,13)$, and it is precisely this quality of magic that appeals to the characters in this novel. For one of the protagonists, a magician by trade, the realm of magic becomes a viable antithesis of the real, offering an opportunity for self-transformation, creativity, and entry into another mode of being. Further, it may be suggested that if Wheeler is right in detecting a residue of religious thought in Swift's fiction (cf. also Lea 2005, 158), then in this novel magic could indeed be seen as a diminished, secular counterpart to faith.

In the words of the reviewer Jon Day, "[d]espite its subject, there's nothing extravagant or showy about Here We Are" (2020). It is written in Swift's favourite mode of meandering recollections, "suffused with nostalgia, both sweet and sour" (Massie 2020). Its discontinuous narrative is structured around three perspectives and two temporal planes. Contrasted are seventy-five-year-old Evie's present loneliness and sense of loss on the one hand, and, on the other, an account of her season in Brighton as a magician's assistant back in 1959. That memorable summer is evoked also through the consciousness of two young men - Ronnie the magician, whom Evie was going to marry at the end of the season, and Jack, a fellow stage performer, whom she eventually chose as her husband. Jack has recently died, while Ronnie mysteriously vanished years ago, after the season's final performance, never to be seen again. This sketchily told, simple story is complemented by an account of Ronnie's childhood and his wartime evacuation to a country house. In his review of the novel, Lindsay Duguid describes it as "an old-fashioned story told in an old-fashioned style" but asserts that "Swift's method is to set down ordinary things so as to suggest something more" (2020). By combining the ordinary with "something more," the novel manifests an affinity with most of his previous fiction.

Magic plays a key role in the flimsy plot of Here We Are. Although the three perspectives are proportionately interwoven in the narrative, it is the magic practised by Ronnie that dominates the relations between the characters, just as it was magic that brought the three of them together in the first place. Ronnie and Jack first met during their national service, when they discovered a shared interest in the performing arts. Afterwards, the resourceful Jack offered Ronnie a part in the Brighton show he directed, advising him to advertise for an assistant to make his tricks more attractive. Evie and Jack's fifty-year long marriage, which followed the season in Brighton, was inextricably linked to their joint career in the entertainment business. Now, contemplating her old face in the mirror, Evie can also visualise her past, and half expects one or the other man to appear in her looking glass, as if brought back by magic. 


\section{In the Realm of the Magical}

As the above synopsis indicates, different meanings of "magic" are intimated and exploited in the novel. In the most obvious sense, magic is Ronnie's profession, a set of skills that enable him to perform tricks to surprise and dazzle his audience. Magical tricks are calculated to mask the mechanisms of the performance and stage events that seemingly defy the laws of physics, while the audience accepts that the deception of their senses is a vital part of the game. Tanya Luhrmann defines magic as "the deliberate attempt to fool an audience that knows that it is being fooled" (after Jones 2011, 12). In a colloquial sense, "magical" is synonymous with "extraordinary" and "exceptional"; magic is "[a] quality of being beautiful and delightful in a way that seems remote from daily life" (Oxford English Dictionary) - and this is what first drew Ronnie to this profession, which offered an alternative to the narrow confines of his life and the finiteness of his self. The notion of magic may be invoked to describe what appears wondrous, improbable, implausible, or coincidental. However, this colloquial use is rooted in the original meaning of magic, i.e. "the power of apparently influencing events by using mysterious or supernatural forces," as the Oxford English Dictionary puts it. In this last sense, magical practices approximate religious rituals. The two may overlap to such an extent that anthropologists regard the boundary between them as fluid. As Shawna Dolansky notes, "Both magic and religion claim access to realms outside of ordinary reality and attempt to manipulate supernatural forces for desired outcomes in the natural world" $(2008,4)$. While Dolansky's claim is mostly derived from her study of the interactions and correspondences between Israelite worship and pagan rites in the times of the Old Testament, ${ }^{2}$ in modern societies belief in the supernatural potential of magic is treated as a degenerate form of religion. Daniel Dubuisson argues that although belief in magic is motivated by similar aims and desires, it is no more than a form of superstition which offers at best a semblance of what religion promises. Magic, he asserts, lacks any grand intellectual framework, an overarching metaphysical structure, or the synthesising power of a religious system $(2016,176)$. Magical activity can only operate on a small scale, affecting "the personal situation of this or that individual. The universe of its humanity is made of 'small worlds' (the village, the tribe) that conform to the size of man" (175-76). Whereas magic, unlike religion, cannot make the crucial promise of immortality, it still offers a form of respite. To quote Dubuisson again:

it could slide into the gaps left vacant by religion in order to respond to the pressing expectations of poor human creatures who felt impotent before misfortune and unhappiness. And so desirous of escaping them - not for eternity or even for the duration of their life, but simply for this one time... (176)

2 To illustrate the overlap, she cites the proximity between Moses' actions and the practices of Egyptian magicians (4). 
In Swift's story, the magic that Ronnie and his fellow artists proffer to their audience has no power to change everyday reality but it provides a temporary escape from it; it is not expected to alter anybody's life, yet it can transport the audience away from their run-of-the-mill preoccupations. Indeed, Ronnie's performance is the culmination of the Brighton pier show, which itself is supposed to be the climax of one's holiday:

The important thing was to send them all out with their holiday mood endorsed, feeling they'd had their money's worth, they'd had a good time, making them even feel they might sing and dance a bit themselves. For many of them, an evening at the pier show was the highlight. (2020, 7-8).

The chief appeal of the holiday-time performance lies in its opposition to the dullness of ordinary life: "There comes a sad point in any holiday when you start to think: Only so much more of this left now; then back to the real world" (157). Entertainment magic is made possible because people wish to be mystified and amazed, shaken out of their habitual experiences. Alluding to Viktor Shklovsky's concept of defamiliarisation, Jones emphasises magic's "ability to challenge people's grasp on reality" (2011, 13). Magic, he claims, "destroys" reality and thus enhances people's awareness of the processes of perception, presenting them with strange and unfamiliar phenomena (13).

The existence of an (artificially erected) boundary between the dreariness and familiarity of real life on the one hand, and, on the other hand, the glamour and strangeness of the illusion of magic is continually stressed in Swift's novel. Extraordinary things happen on stage; the artists wear alluring costumes and adopt different personas, having provisionally shed their usual selves. The gap separating the two domains is exposed when the characters have to move between them. Jack, for example, has his private ritual as he prepares to appear before his audience; he exhorts himself: "Cross the line, step over the edge" (4). Likewise, Evie and Ronnie are aware of the discrepancy and incongruity between their stage and offstage lives:

It was all rather odd. One moment they were doing magic - they really were - next, they were stopping for tea. She sometimes made it herself now, they took it in turns. And it must have looked very odd too, a woman sometimes in little more than sequins and plumes in that cubbyhole, with its stained and smelly sink, filling the kettle, warming the pot. (72-73)

Increasingly attracted to Evie, Jack develops a habit of watching her performance from the auditorium, which involves him stepping out of his role as compère and acknowledging the fragility and pretence of the illusion they have jointly created: "he would sometimes feel the thinness, the fakery of the plush rapt edifice around him." A closer look might reveal that all the supposed glamour was in fact "tatty," "shabby" and "sham" (103). The illusion, with all the attractions it promises, is wholly predicated on the audience's willingness to believe in it. The ephemerality of the Brighton 
show is enhanced by the instability and precariousness of its location - a wooden platform suspended over the sea.

For a brief period, in parallel to the magic they create on stage, Ronnie's and Evie's private lives take a turn towards the wondrous and the enchanted. They fall in love and become engaged soon after starting to work together. By a happy coincidence, or a stroke of magic, the only candidate who answered his advertisement becomes Ronnie's special woman. This is how they represent it to themselves: "Ronnie and Evie owed to Jack that they were there at all - even, it could be said, that they had become engaged. Thus Jack himself had woven a kind of magic" (13-14). However, from Ronnie's perspective, the magical intervention in his life proves just as whimsical and short-lived as the illusion he creates for his audience - before the season is over, Evie transfers her affections to Jack.

The protagonist's commitment to magic exceeds a merely professional interest. Not only can he offer his audience temporary amazement and an escape from the banality of their everyday life, but, by practising magic, he transforms himself as well. Magic captured Ronnie's imagination in childhood, when, thanks to a combination of unforeseen circumstances, it fortuitously responded to his need for dream, illusion and fantasy. Ronnie was one of the numerous children evacuated from London during the Blitz. However, far from being traumatic, the experience of dislocation proved liberating and enriching. The years spent with the Lawrences in their country house changed him permanently. The later split between reality and his stage life is foreshadowed by the boy's introduction to what is to him a very different social milieu. The Lawrences' upper-middle class lifestyle, the beauty of the Oxfordshire landscape and the grandeur of their house are a world apart from the shabbiness of Ronnie's London home. In comparison with his own place, his new surroundings have an aura of the exotic so that he initially wonders if they are real at all. Sensing the incompatibility of his two homes, he carefully keeps the two spheres separate, revealing little about his London life to the Lawrences, and, likewise, keeping the character of his new life secret from his mother. Ronnie is aware of the duality in his experience, as well as conscious of the growing appeal of the world that has opened up for him: "How could you have had one life and then simply exchanged it for another?" (44). For Ronnie, the name of the Lawrences' house, Evergrene, encapsulates the otherworldly quality of the place, whereas Mr Lawrence's occupation appears to chime in with what the house stands for: everlasting wonder. By the time he receives the news of his father's death at the front, Ronnie already has a surrogate father in the person of Eric Lawrence and has been won over by the magic that his new father wields:

Why had he cried? For his father certainly, but also for some great swamping confusion - confusing yet kind. For this extraordinary metamorphosis that had occurred in his life. For the boy, weeping before on a train, who'd not known any of this was to come - who'd cried then for his mother, for whom he was not crying now. From guilt and dismay that he could cry now for his father yet feel that had another already to replace him. [...] He had discovered by now his purpose in life. He had discovered, or it had been revealed to him, that Mr Lawrence was not just 
the owner with his wife of an enchanted place called Evergrene, but, though currently forced to work in a limited way [...], he was an accomplished magician. (47-48)

At this moment, Ronnie's conversion to magic is complete. Later, the protagonist looks back on it as his rebirth, "the true start of his life," or the discovery of his "calling" (51). The displacement of his biological father legitimises Ronnie's adoption of a new path in life and a different self.

Ronnie, brought up as the only child in an underprivileged household, was deprived of the opportunity to play; his devotion to magic may be thus a belated fulfilment of his need for fantasy and imaginary play. However, as he is already eight years old when he first arrives at Evergrene, he cannot embrace magic instinctively and uncritically, in the manner of younger children. Magic enters his life at an age when children normally stop believing in the world of fantasy. ${ }^{3}$ Therefore, for Ronnie, magic is a matter of choice - both a profession he learns and a vocation he discovers and consciously pursues. Consequently, his dedication to magic remains permanent - it certainly lasts until his mysterious disappearance.

After the war, Ronnie comes back to London "transformed" (54). His mother's little house has not changed objectively, but in his eyes it now encloses him like a prison. Likewise, his choice of profession, which to his mother seems frivolous and ludicrous, brings about an irreparable breach between them. This is essentially a collision of incompatible perspectives: Agnes's solid commitment to the commonsensical and the material on the one hand, and, on the other, Ronnie's wish to transcend it. His mother briefly cherishes the hope of Ronnie abandoning "this magic poppycock" (117) when he is in the army:

He was doing a "proper job" at last, with regular pay attached to it, some of which he duly sent her. And perhaps a year and a half in the army would knock all that magic rubbish out of him and show him what was about. [...] Thanks to the army, his life had never been more ordinary. The army was even teaching him, in readiness for the great normalities of life, how to be a good little office boy. (60-61)

Yet his devotion to magic prevails. As his girlfriend Evie realises after getting to know him, he has had two childhoods, two lives, two personalities and two names, one for his daily activities and the other, Pablo, reserved for his "magical life" (108).

However, magic in the novel is not only contrasted with reality; it is also shown to have quite narrow limits. Against the constraints and circumstances of real life, magic

3 Discussing the role of play and imagination in a child's development, Claire Golomb asserts that the period between four and seven years is "the highpoint of pretense play" $(2011,113)$. At that age, children easily move between "the realm where imagination and fantasy rule" and "the world of everyday reality" (115). Research also shows that children in that age group tend to believe in the power of magic and that those who practise magic "can fulfill dreams and wishes and perhaps create true transformations" (117). 
is quite powerless. Ronnie's mentor Eric Lawrence warns him early on in his career not to confuse the two meanings of magic: technical adroitness and supernatural powers (or, in a scaled-down form, magical thinking): "There are no magic wands, Ronnie. There are magic wands, but there are no magic wands. Do you understand me?" (58). Magic cannot heal Lawrence's wife after her miscarriage, nor can it prevent Ronnie from losing the love of his life. Likewise, he is unable to bring his mother back to life after narrowly missing the moment of her death ("This is your mother, Agnes. And here's a fine little trick for you to perform, if you're up to it" (129)). The strangers he meets occasionally overestimate his abilities, believing him to be capable of bending reality to their wishes: "Sort out this man's problems, for example. Make money grow on trees, make dreams come true" (127). In admitting his limitations, Ronnie implicitly invokes the distinction between magic and religion: "Magic yes, miracles no" (128).

Nevertheless, some of the tricks he performs do come close to miracles. He can produce objects seemingly out of nowhere, as if creating them ex nihilo; he can transform (or transubstantiate) them into other things; he can also make his assistant appear and disappear. His routines are carefully rehearsed and ritualistically followed, down to the minutest detail, while an element of secrecy and obscurity always remains. Even his assistant does not fully comprehend how certain effects are achieved, and what she does understand she never reveals to anyone. Ronnie's pièce de résistance is conspicuously modelled on a biblical miracle. His show ends with a rainbow appearing above the stage, followed by the flight of a white dove. What the local press hails "the famous rainbow trick" never fails to amaze the audience: "Was there ever applause like it - they had all seen a rainbow - and could there ever have been such a heralding of a career, a life in magic?" (166). During the final show of the season, Ronnie surpasses himself (and eclipses the original miracle) by conjuring up a rainbow-coloured parrot rather than the standard white dove. Although normally reticent about his profession, the protagonist stresses one thing - his conviction that magic is more than a set of tricks. Indeed, Ronnie objects to the commonly used word "trick," insisting that magicians "[do] illusions" instead (123). His purpose is to make his audience momentarily believe in the impossible, to compel them to accept that the laws of the natural world have been suspended: "Illusions, he was known to say, should always be done in good clear light, otherwise people might suspect it was all just - trickery. [...] They were seeing only what they were seeing" (161). As the anthropologist Alexander Goldenweiser observes, the appeal of magic consists in its contradictory impact on the audience: the audience sees something that it knows to be impossible (cf. Jones 201, 12), and this is precisely the effect Ronnie manages to achieve.

"Illusion" is another ambiguous word in the novel, referring both to the extraordinary impressions that magic can produce, and emphasising the element of deception, or delusion, intrinsic to the magician's craft. In Trade of the Tricks: Inside the Magician's Craft Jones asserts that it is in the form of the secular entertainment of magic (also known under the interchangeable terms of "conjuring" or "illusionism") that "illusionary techniques of enchantment have reached their fullest development" 
in modern Western societies $(2011,12)$. Viewed in this light, stage magic may be regarded as a tentative response to what Max Weber a hundred years ago famously called the "disenchantment of the world" (Entzauberung der Welt). ${ }^{4}$ Patrick Sherry notes that the commonly adopted English translation is not entirely suitable, since the concept literally refers to the world "losing its magic" (2009, 369), or, as Eu Jin Chua explains, "the word connotes the breaking of a magic spell."

Weber's formulation is generally taken to describe "the elimination from our conceptual world of those powers aroused or manipulated by magical techniques" (Grosby 2013,301). This process, according to Weber, concurred with the emergence of modernity following the Enlightenment, in particular the processes of "intellectualization and rationalization" (Weber 1958, 117), and entailed the questioning of supernatural forces as the causes of the phenomena observable in the social and natural world. The transformation presupposed, as Weber put it in "Science as a Vocation," that:

there are no mysterious incalculable forces that come into play, but rather that one can, in principle, master all things by calculation. This means that the world is disenchanted. One need no longer have recourse to magical means in order to master or implore the spirits, as did the savage, for whom such mysterious powers existed. $(1958,117)$

The belief in the supernatural was gradually displaced by scientific, rational explanation. Hence, according to Weber, modernisation and secularisation went hand in hand. While there are no obvious symmetries between these processes and many religious practices remain firmly in place in modern societies, as a result of "disenchantment" religious beliefs have nevertheless lost their central function in organising social life (Kumar 1999/2020). Although the term "disenchantment" appears to connote nostalgia, it emerges from Weber's reasoning that he did not lament the passing of the old world; on the contrary, he regarded the transition as inescapable and, generally, advantageous (Sherry 2009, 369-70). However, from a contemporary perspective, it is clear that the supposedly beneficial liberation from illusions is not quite the outcome of the modernist project that Weber envisaged. Indeed, a desire for some form of spirituality is not uncommon in the postmodern age. In The Re-enchantment of the World: Secular Magic in a Rational Age (2009), Joshua Landy and Michael Saler argue that Weber's account is incomplete because it fails to acknowledge the countertendency: when religion withdraws from a certain area of experience, the void is filled in by a secular form of re-enchantment (1). Despite progressive rationalisation, philosophers, artists, writers, stage magicians as well as ordinary men and women have a range of strategies to restore a sense of mystery and wonder to the modern profane world (2-3).

4 Weber introduced the concept in his most famous work, The Protestant Ethic and the Spirit of Capitalism (1904-5), and subsequently elaborated on it in his essay "Religious Rejections of the World and their Directions" (1915) as well as in his lecture "Science as a Vocation," delivered in Munich in 1917. 


\section{Re-enchanting Private Worlds}

Whereas it would certainly be far-fetched to assume that Swift's protagonist seeks religious experience, it is clear that Ronnie is anxious to endow his dull, narrow world with some sense of awe and mystery, or, in other words, some "enchantment." The prospect of a different realm first opens up to him at Evergrene. Accordingly, as he later perfects his skills, the quality of his show changes - he moves beyond technical tricks to what he calls "wizardry": "He could see the land of wizardry beckoning to him. [...] And it was not simply a show-business region, he knew this, it was a different world altogether, it had different laws, it made different demands" (119-20). In his capacity as magician, Ronnie can transcend his daily selfhood; while on stage, he becomes "possessed" (121), as if he performed a ritual; even on the first occasion when he practises magic he feels "a strange power" (137). The illusions he creates have a personal resonance for him insofar as they help him counter the losses and disappointments of his private life. His final trick, the parrot he conjures up in front of his mesmerised audience, is in fact a magical recreation of the bird he once received from his father, which his mother later sold as useless. At the time, his mother's brutally down-to-earth action struck him as "a sharp lesson in the ways of the world" (21), and possibly instigated the desire to eschew such a practical approach.

However, Ronnie's tricks - or illusions, as he prefers to call them - offer only a temporary diversion rather than a chance to permanently change anything in the real world, either for him or his audience. With Ronnie gone, the magic he created dissolves too. The secrets of his trade will never be disclosed. A police investigation into his disappearance is launched; Evie and Jack are faced with a scarcity of evidence concerning Ronnie's life. Obviously, Ronnie disappeared on purpose - he took his last bow and went missing, together with all his possessions, as if his apparent self-dematerialisation was the final part of his show. Indeed, his vanishing act brings about one more confrontation between illusion and reality. In an attempt to find Ronnie, Evie travels to Evergrene, expecting that he might have gone back to his magical place, yet finds the house not only deserted but also deprived of any associations with the magic Ronnie recollected - "a strange, rather bleak disappointment" (177):

There was nothing to suggest the mansion full of wonders that Ronnie had seemed to evoke whenever she'd got him, sometimes with much effort, to speak of it. [...] You would have said, very readily, that it had no magic. It had been thoroughly cleared, and inside it was drab and echoey. (178)

Ronnie's final act obliquely hints at the role played by magic in confrontation with mortality. Ronnie had found out on several occasions that magic is ineffective against the ultimate problem of death. Still, the manner of his disappearance may be seen as an illusionistic and illusory way of defying this limitation. 
Fifty years on, Evie, the only remaining protagonist, remembers her two lovers, and contemplates two kinds of passing. Jack died in his sleep, and she was faced with the materiality of his dead body. Now she finally lays him to rest by scattering his ashes under a tree. Soon she reflects that she could have chosen a different place, which, by dint of its liminality, metonymically represents the borderline between the land of the living and the fluidity of dissolution: "In the sea, in the sea, from the end of Brighton pier even" (152). The idea is conspicuously reminiscent of the final scene in Last Orders, in which Jack's friends carry his remains as far as the end of the Margate pier: "the ash I carried in my hands, which was the Jack who once walked around, is carried away by the wind, is whirled away by the wind till the ash becomes wind and the wind becomes Jack what we're made of" (1996, 294-95). Obviously, the image of a handful of dust, whether the ashes of Jack Robinson in the hands of Evie or the ashes of Jack Dodds in the hands of his friends, constitutes a long-established reminder of mortality. The irrefutable evidence of Jack's demise leaves Evie with an overwhelming sense of loss, which only the fantasy of his reappearance may occasionally alleviate: "how could you bear it, live with it, without that teasing, rescuing illusion?" (193).

The materiality of Jack's death is counterpointed by the mystery of another kind of passing, a kind that leaves no material trace and therefore, paradoxically, arouses some hope of a reunion. Ronnie's successful disappearing trick was a highly equivocal gesture: the dissolution of magic was simultaneously its affirmation, also leaving open the possibility that he might reappear one day. The incertitude he created helps to sustain the saving and comforting illusion of magic. Evie occasionally fantasises about one or the other man miraculously stepping back into her life: "And sometimes [...] she'd thought [Jack] really had walked into the house. Or someone had." As she is falling asleep at the end of the day (and the end of the novel), a reunion seems to her quite an attainable vision: "And if Jack, then why not Ronnie? Would it be so extraordinary, given what he'd given his life to?" (194). The epigraph to the novel quotes a line from Joni Mitchell's song: "It's life's illusions I recall." The retrospective song, which juxtaposes dreams and reality, resonates with the novel's depiction of actual magical illusions. Eventually, the heroine finds some comfort in her recollections. The dream fantasy, the illusion of magic and the delusion triggered by grief all merge in Evie's mind as her day is - to quote Prospero - "rounded with a sleep."

Certain parallels may be found between Here We Are and Mothering Sunday (2016), the novel which immediately preceded it. It portrays an aged woman reminiscing about her fairy-tale transformation from a poor orphan to a successful writer. Jane's early passion for reading led to a career as a creator of fiction. A turning point in her life was the moment when her employer allowed her to use his library - in simple yet "magic, door-opening words" (2016: 67). Looking back, the heroine is pleased to have spent her life in the realm of the imaginary. 


\section{Conclusion: The Need for Illusion}

If the practice of magic itself is a new element in Swift's fictional universe, other forms of illusion are not. The protagonists in his latest novel demonstrate an affinity with some of his other characters by seeking to transcend the mundanity, nullity and drabness of their existence. In Swift's fiction such attempts are, as a rule, partially rewarding but ultimately disappointing. In Waterland, Tom Crick's fairy-tale life in the Fens comes to an abrupt end when his school friend's body is found in a canal. This harsh encounter with the here and now, followed by other traumatic experiences, teaches him to distrust illusions as well as prepares him to later probe and critically explore "grand narratives," primarily the metanarrative of history. ${ }^{5}$ In the world of Ever After, as Malcolm observes, "[i]llusion is absolutely necessary." Assessing the narrator's attitude, the critic speaks of illusion as a wilfully concocted and self-consciously embraced fabrication: "This is a world of transience, death, chaos, and betrayal. In such a world, Unwin asserts the importance of illusions, of fictions, of lies. That is all there is to set against the grim consuming fires of this world" $(2003,155)$. Ultimately, however, the narrator, having survived a suicide attempt, faces the erosion of his beliefs and illusions. Embedded within his narrative is the story of his Victorian ancestor struggling with a crisis of faith in the face of scientific facts. If Matthew Pearce experienced the kind of "disenchantment" that Max Weber was to define, then his late twentieth-century descendant created his own illusions in an attempt to re-enchant his private world.

The word "divine," which recurs in Ever After, is used by Unwin's mother to express pleasure and delight, but, besides this colloquial sense, the word obviously carries other connotations. Referring to Ever After, Swift said in an interview that "there are certain moments, certain experiences in life where you feel that something extraneous to normal existence has occurred, and it has to be registered in words like 'divine,' which are used by unreligious people to register something that is almost religious" (Bernard 1997, 223). The word "magical" clearly belongs to the same category. Here We Are is modest in size and subject matter, it makes no metaphysical claims and refers to no overarching systems of thought. The novel creates a very narrow world, with none of the "consuming fires" of Ever After or the grandiose intellectual framework of Waterland. However, paradoxically, it is thanks to its limited scope that stage magic, with its awe-inspiring defiance of natural laws and its sense of mystery and ritual, offers an accessible and feasible way of tackling the dearth of enchantment in contemporary life. In Here We Are, the magical is continually intertwined with the mundane, sustaining the heroine in her last moments before she slips into the oblivion of sleep (or, perchance, a dream). Magic is powerless against mortality, but the indeterminacy

5 Cf. David Malcolm's comment on the use of story-telling in Waterland: "the narrator continually problematizes the relationship of story and reality, presenting narrative as, at once, an evasion of reality and a necessary means of dealing with the hideous absurdity and meaninglessness of historical events" $(2003,97)$. 
of the magician vanishing into thin air helps to maintain the simple, consoling illusion of the possibility of a reunion.

Here We Are, like the majority of Swift's fiction, is tinged with sorrow and a sense of transience, yet what prevails in the character's retrospection are memories of a satisfying life that managed to transcend the mundane. In Mothering Sunday, the optimistic, fairy tale-like story marked a change of tone compared with Swift's previous narratives. Viewed in conjunction, the two recent novels possibly point to a new tendency in his writing, towards portraying characters who find genuine comfort in the extraordinary fictional world of their own making.

\section{References}

Bernard, Catherine. 1997. “An Interview with Graham Swift.” Contemporary Literature 38 (2): 217-231. doi: 10.2307/1208781.

Chua, Eu Jin. [n.d.]. “Disenchantment.” In Encyclopaedia Britannica. Accessed June 29, 2020. https://www.britannica.com/topic/disenchantment-sociology.

Craps, Stef. 2009. "An Interview with Graham Swift." Contemporary Literature 50 (4): 636661. doi: $10.1353 /$ cli.0.0086.

Day, Jon. 2020. "Here We Are by Graham Swift - the Magic of Fiction." Financial Times, February 27. Accessed June 19, 2020. https://www.ft.com/content/32ed4326-53d2-11eaa1ef-da1721a0541e.

Dobrogoszcz, Tomasz, and Marta Goszczyńska. 2020. “Introduction.” In Reading Graham Swift, ed. Tomasz Dobrogoszcz and Marta Goszczyńska, vii-xv. Lanham: Lexington Books.

Dolansky, Shawna. 2008. Now You See It, Now You Don't: Biblical Perspectives on the Relationship Between Magic and Religion. Winona Lake, Ind.: Eisenbrauns.

Dubuisson, Daniel. 2016. Religion and Magic in Western Culture. Boston: Brill.

Duguid, Lindsay. 2020. "What Really Happened. Nostalgia and Loneliness in Graham Swift's Here We Are." Times Literary Supplement, March 6. Accessed June 19, 2020. https://www. the-tls.co.uk/articles/graham-swift-here-we-are-review-lindsay-duguid.

Golomb, Claire. 2011. The Creation of Imaginary Worlds: The Role of Art, Magic and Dreams in Child Development. London: Jessica Kingsley Publishers.

Grosby, Steven. 2013. "Max Weber, Religion, and the Disenchantment of the World." Society 50 (3): 301-310. doi: 10.1007/s12115-013-9664-y.

Jones, Graham M. 2011. Trade of the Tricks: Inside the Magician's Craft. Berkeley: University of California Press.

Kaczvinsky, Donald P. 2020. "Here We Are." World Literature Today 94 (3): 98-99.

Kakutani, Michiko. 2015. "Review: Graham Swift's England and Other Stories: A Darkness across Time and Fates." The New York Times, 22 June. Accessed June 19, 2020. https:// www.nytimes.com/2015/06/23/books/review-graham-swifts-england-and-other-stories-adarkness-across-time-and-fates.html. 
Kumar, Krishan. 1999, rev. and updated 2020. "Secularization and Rationalization." In Encyclopaedia Britannica. Accessed January 3, 2021. https://www.britannica.com/topic/modernization/Secularization-and-rationalization.

Landy, Joshua, and Michael Saler. 2009. "Introduction: The Varieties of Modern Enchantment." In The Re-Enchantment of the World: Secular Magic in a Rational Age, ed. Joshua Landy and Michael Saler, 1-14. Stanford: Stanford University Press.

Lea, Daniel. 2005. Graham Swift. Manchester and New York: Manchester University Press.

Malcolm, David. 2003. Understanding Graham Swift. Columbia: University of South Carolina Press.

Massie, Allan. 2020. "Book Review: Here We Are, by Graham Swift." The Scotsman, 10 March. Accessed June 19, 2020. https://www.scotsman.com/arts-and-culture/books/book-reviewhere-we-are-graham-swift-2446021.

Oxford English Dictionary. [n.d.]. Accessed June 17, 2020. https://www.oed.com.

Scholes, Lucie. 2014. "England and Other Stories Review - Graham Swift's Affectionate Chronicle of Everyday Lives." The Guardian, 3 August. Accessed June 5, 2019. https:// www.theguardian.com/books/2014/aug/03/england-other-stories-review-graham-swift-affectionate-chronicle-everyday-lives.

Seiffert, Rachel. 2014. "England and Other Stories, by Graham Swift." The Financial Times, July 18. Accessed June 5, 2019. https://www.ft.com/content/543e369a-0b47-11e4-9e5500144feabdc0.

Sherry, Patrick. 2009. "Disenchantment, Re-Enchantment, and Enchantment." Modern Theology 25 (3): 369-386. doi: 10.1111/j.1468-0025.2009.01533.x.

Swift, Graham. 1984 [1983]. Waterland. London: Picador in association with Heinemann.

Swift, Graham. 1988. Out of this World. London: Picador.

Swift, Graham. 1992. Ever After. London: Picador.

Swift, Graham. 1996. Last Orders. London: Picador.

Swift, Graham. 2003. The Light of Day. London: Hamish Hamilton.

Swift, Graham. 2011. Wish You Were Here. London: Picador.

Swift, Graham. 2016. Mothering Sunday: A Romance. London: Scribner.

Swift, Graham. 2020. Here We Are. London: Scribner.

Weber, Max. 1958. "Science as a Vocation." Daedalus 87 (1): 111-134.

Wheeler, Wendy. 1999. "Melancholic Modernity and Contemporary Grief: The Novels of Graham Swift." In Literature and the Contemporary: Fictions and Theories of the Present, ed. Roger Luckhurst and Peter Marks, 63-79. Harlow: Longman. 